\begin{tabular}{|c|c|c|}
\hline ב & $\begin{array}{c}\text { International Journal of Current Research } \\
\text { and Academic Review }\end{array}$ & \\
\hline $\begin{array}{l}\text { EXCELLENT } \\
\text { PUBLISHERS } \\
\text { PUBLE }\end{array}$ & $\begin{array}{c}\text { ISSN: 2347-3215 (Online) Volume } 6 \text { Number } 4 \text { (April-2018) } \\
\text { Journal homepage: http://www.ijcrar.com }\end{array}$ & \\
\hline
\end{tabular}

doi: https://doi.org/10.20546/ijcrar.2018.604.004

\title{
Nanotechnology: Current Scenario and Future Aspects
}

\author{
M. Durairasu and V. Indira* \\ Department of Zoology, Presidency College, Chennai, Tamil Nadu, India \\ *Corresponding author
}

\section{Abstract}

Nanotechnology is one branch of modern applied sciences that comprises of biology, physics, chemistry and material sciences and it is largely exploited for the enhancement of develops novel therapeutic agents, nano sized materials for biomedical and pharmaceutical applications etc. The biological syntheses of nanoparticles are mainly done by living organisms such as plant, bacteria, fungi, seaweeds and microalgae. Microbial based nanoparticles fabrication is mainly depending upon extracellular and intracellular enzymatic activities. Plants are enriched with several bioproducts such as alkaloids, flavonoids, saponins, steroids, tannins and other nutritional compounds. These natural products play an important role in the synthesis of plant based nanoparticles, moreover plants also comprises of secondary metabolites that could generate nanoparticles. Biogenic approaches are employed for the synthesis of many metallic nanoparticles such as cobalt, copper, silver, gold, palladium, platinum, zinc oxide and magnetite. These biogenic nanoparticles possess lot of biotechnological applications that could be exploited for the betterment of the society.
\end{abstract}

\section{Article Info}

Accepted: 07 March 2017

Available Online: 20 April 2018

\section{Keywords}

Microbial mediated nanoparticles, Nanotechnology,

Plant mediated synthesis of nanoparticles

\section{Introduction}

Nanotechnology is one among the most promising research area in applied sciences due to its peculiar properties related to size, shape, distribution and morphology than large particles from which the nanoparticles are made (Suresh et al., 2011). Nanotechnology encompasses the construction, operation and use of materials ranging in size less than a micron to that of individual atoms. The synthesis of nanoparticles with precise size, shape, composition has explored the possibility of their applications in various fields including agriculture, cosmetics, textiles, food, medicine and environment (Kumar et al., 2014). The surface area ratio of nanoparticles is inversely proportional to their size, due to which it is explored in optoelectronics, in catalysis, photonics, biological tagging and pharmaceuticals. Despite of having several methods for the synthesis of nanoparticles, it is essential to develop more efficient and low cost methods (Mariselvam et al., 2014). Biogenic nanoparticles have evolved dominant over its synthetic counterparts due to its elevated biocompatibility and immediate synthesis. In this review we are discussing about some of the major biogenic approaches of nanoparticle fabrication and its biotechnological applications.

\section{Microbial mediated nanoparticles synthesis}

Several microorganisms such as bacteria, fungi, yeast and algae have been reported for its ability to synthesis nanoparticles by reducing metal ions into nanoparticles. 
The nanoparticles synthesized from this microorganisms have found application in various fields and more biocompatible compared with chemically synthesized counter products (Krishnaraj et al., 2014). There are two various methods through which microbial nanoparticles are formulated, intracellular synthesis and extracellular synthesis (Davis et al., 2003). Intracellular synthesis method involves a specific ion transportation system in the microbial cell. In this the cell wall of the microorganism plays an important role in biosynthesis of metallic nanoparticles (Cai et al., 2011). The main mechanism behind cell wall mediated intracellular nanoparticles synthesis is the electric charge of metal ions and cell wall. The cell wall of microorganism is negatively charged and the metal ions contain positive charge, so that there will be an electrostatic interaction force between this two opposite charges (Du et al., 2007) due to which both will be attracted to each other after which the enzymes present in the cell wall of microorganisms reduce these metal ions into nano scale to form nanoparticles (Figure 1). Hence formulated nanoparticles will be later diffused out through cell wall. The mechanism of extracellular synthesis of nanoparticles involves the action of nitrate reductase enzyme which will convert the metal ions to nanoparticles (Luo et al., 2014). However, several microorganisms have been found secreting nitrate reductase enzyme which assist the conversion of metal to metallic nanoparticles.

\section{Biodiversity of microorganisms fabricating nanoparticles}

There have been many bacterial isolates that are delineated for its ability to synthesis nanoparticles. A Geobacter sp. Magnetospirillum magnetotacticum have found to produce metal nanoparticles through reduction of $\mathrm{Fe}$ (III) where it intake toxic metals like $\mathrm{Fe}$ (III) through reduction, where iron is actively taken by the cell, re-oxidized to hydrous oxide (low density) to Fe(III) oxide (ferrihydrite), which is of high density. The Fe(III) ions in the last step is reduced and magnetite is produced from dehydration within the magnetosome vesicles. An intracellular protein Ferritin, accumulates the iron within the vesicles keeping it in non-toxic and soluble form. The nanoparticles produced have following characteristics like high purity, little crystalline defects, narrow size, mono-dispersive etc. Similarly the thermophilic bacteria can be an excellent tool for the extracellular synthesis of both gold and silver nanoparticles as the extracellular systems produce an environment-friendly alternative for huge quantities of nano materials reducing the downstream processing of these metals (Gomathy and Sabarinathan, 2010). The MDR (multi-drug resistance) bacteria that have gained its importance due to antibiotic resistance can also be exploited for the synthesis of nanoparticles that can act against pathogenic strains (Menon et al., 2017). Likewise fungal strains can also be used for the synthesis of nanoparticles. The property of fungi to secrete large amount of enzymes could be of good aid in nano particle fabrication (Fayaz et al., 2011). The filamentous fungi have unique advantages over other microorganisms like bacteria and algae, as they have high metal tolerance and have the capability of bioaccumulation. They are helpful in the scaleup, handling of biomass, downstream processing, economic viability and they also secrete extracellular enzymes, of which large scale production is easily possible. The biochemical composition, shape and size distribution of the nanoparticles are controlled by the active biomolecules produced by the fungal organisms. The gold ions were absorbed by them and that led to the formation of the gold nanoparticles produced intracellularly. The active molecules involved can be reducing sugars, proteins, like ATPase, glyceraldehyde-3-phosphate dehydrogenase, 3-glucan binding proteins; all are involved in the energy metabolism of the cells of the fungi. The Au-fungal cells ultrathin sections when studied, it was found that gold nanoparticles were gathered in the vacuoles of the cells (Suganya et al., 2015).

The actinomycetes are exploited in a large amount for the synthesis of nanoparticles as it can be easily undergo genetic modification for the attainment of better size and poly-dispersed nanoparticles (Ahmad et al., 2003). The actinomycetes have a closer resemblance with the fungi and the prokaryotes characteristics like the bacteria (mycobacteria and the coryneform). They are currently being used in the nanotechnology as they have the ability to produce secondary metabolites like antibiotics (Zhang et al., 2011). Algae, the photoautotrophic, eukaryotic, aquatic, oxygenic microorganism have the ability to accumulate heavy metals, due to this fact; researchers are finding cleaner techniques for the preparation of nanoparticles. This represents a good advantage of using algae as an abundant raw material source (Castro et al., 2012). Fucoidans are polysaccharide secreted from the cell walls of marine brown algae and that has proved to possess many applications in diverse fields like the anticoagulant, anti-inflammatory, anti-viral and also anticancer. They are also being used in the cosmetic industries as an anti-aging or whitening agents. The synthesis of gold nanoparticles from these fucoidans has 
proved to a fruitful alternative to the chemical methods (Lirdprapamongkol et al., 2014). The brown algae has been exploited more as compared to other species due to its ability of uptake of heavy metals. They have a complex cell wall which is rich in mucilaginous polysaccharides, which explain the heavy metal uptake clearly. Also, it contains functional groups like the carboxyl groups, which are involved in the uptake (Venkatesan et al., 2014). There have been many more microorganisms with the ability to synthesis nanoparticles and some of them are elaborated in Table 1.

\section{Plant mediated synthesis of nanoparticles}

Recently, the plant mediated nanomaterial has drawn more attention due to its vast application in various fields due to their physic-chemical properties(Suriyakalaa et al., 2013). The different metallic nanoparticles such as gold, silver, platinum, zinc, copper, titanium oxide, magnetite and nickel were synthesized from natural resources and have been studied exclusively. The different parts of plant such as stem, root, fruit, seed, callus, peel, leaves and flower are used to syntheses of metallic nanoparticles in various shapes and sizes by biological approaches. Biosynthesis reaction can be altered by wide range of metal concentration and amount of plant extract in the reaction medium, it may transform the shapes and size of the nanoparticles(Thakkar et al., 2010).

\section{Biodiversity of various plants with nanoparticles synthesis capacity}

Numerous plants have been identified for the ability of nanoparticles fabrication. For instance Callicarpa maingayi stem methanolic extract successfully generated silver nanoparticles and formed [Ag (Callicarpa maingayi) $]^{+}$complex. The plant extract contains aldehyde group and it's mainly involved in the reduction of silver ions into metallic $\mathrm{Ag}$ nanoparticles. The different functional group $\mathrm{AC}, 0, \mathrm{C}, \mathrm{N}$ indicates amide I, polypeptides which are the responsible compounds in the capping of ionic substances into metallic nanoparticles (Shameli et al., 2012). The molecular studies on biosynthesis of silver crystals are complex and not yet fully understood. But some previous studies are proposed model mechanisms of nanoparticles interaction with pathogenic organisms. The biosynthesized silver NPs binding with protein outer cell wall of bacteria, fungi or viral bodies that breaks the lipoproteins of microbial cell wall. Finally the cell division was stopped and cell leads to death. Phytosynthesis of silver nanoparticles use Cissus quadrangularis extracts at room temperature was reported by Vanaja et al., (2013) possessed antagonistic activity towards Klebsiella planticola and Bacillus subtilis pathogenic bacteria

Gopinath et al.,(2012) used plant fruit bodies Tribulus terrestris extract with addition of different molar concentrations of silver nitrate solution in order to synthesize eco-friendly AgNPs with specific morphological features. The extract contains active phytochemical compounds that are liable for the single step reduction reaction. The spherical shapes of silver nanoparticles were produced by the T. terrestris extract and substantiated admirable antimicrobial activity against multidrug resistant human pathogens. There is similar report on using of polyphenol from grapes to synthesize palladium nanoparticles and act effectively against bacterial diseases (Amarnath et al., 2012). In addition, Rumex hymenosepalus extract acts as a reducing and stabilizing agent for silver nanoparticle synthesis.

The use of optimum physic chemical parameters to synthesize nanomaterial is very effective in pharmacological solicitation to treat various endemic diseases. The fenugreek seed extract contains high flavonoids and other natural bioactive products such as lignin, saponin and vitamins. The reduction of chloroauric acid by using the powerful reducing agents fenugreek seed extract acts as a better surfactant. The $\mathrm{COO}_{-}$group (carboxylic), $\mathrm{C}, \mathrm{N}$ and $\mathrm{C}, \mathrm{C}$ functional groups are present in the seed extract. The functional group of metabolites acts as a surfactant of gold nanoparticles and the flavonoids can stabilize the electrostatic stabilization of gold NPs (Mittal et al., 2013). The aqueous extract of Macrotyloma uniflorum enhanced the reduction rate of silver ions. This may be owing to the presence of caffeic acid in the extract. Therefore, the presence of caffeic acid reduction reaction was occurred within a minute. Plant leaves extract used as a mediator to synthesis of nanoparticles was reported. Leaves of Centella asiatica, Murraya koenigii, Alternanthera sessilis and many plants leaves extract have been studied. Recently, $P$. nigrum leaves were stated to contain an important bioactive compound which is involved in the nanoparticle synthesis by eco-friendly method. The biological mode of synthesized silver nanoparticles of $100 \mathrm{lg} / \mathrm{ml}$ concentration was proficient drug concentration on HEp-2 and HeLa cell line to regulate the normal biochemical function in cancer cells. 
Table.1 Summary of plant derived metallic nanoparticles and its biomedical applications (Kuppusamy et al., 2016)

\begin{tabular}{|c|c|c|c|c|c|}
\hline Plants used & Nanoparticles & $\begin{array}{l}\text { Parts of } \\
\text { plant }\end{array}$ & $\begin{array}{l}\text { Size } \\
(\mathrm{nm})\end{array}$ & $\begin{array}{l}\text { Plant metabolites } \\
\text { involved in } \\
\text { bioreduction }\end{array}$ & $\begin{array}{l}\text { Pharmacological } \\
\text { applications }\end{array}$ \\
\hline Acalypha indica & $\mathrm{Ag}, \mathrm{Au}$ & Leaves & $20-30$ & $\begin{array}{l}\text { Quercetin, plant } \\
\text { pigment }\end{array}$ & Antibacterial \\
\hline Aloe vera & $\mathrm{In} 2 \mathrm{O} 3$ & Leaf & $5-50$ & Biomolecules & Optical properties \\
\hline Alternanthera sessilis & $\mathrm{Ag}$ & Whole & 40 & $\begin{array}{l}\text { Amine, carboxyl } \\
\text { group }\end{array}$ & $\begin{array}{l}\text { Antioxidant, } \\
\text { antimicrobial }\end{array}$ \\
\hline $\begin{array}{l}\text { Andrographis } \\
\text { paniculata }\end{array}$ & $\mathrm{Ag}$ & Leaves & $67-88$ & $\begin{array}{l}\text { Alkaloids, } \\
\text { flavonoids }\end{array}$ & $\begin{array}{l}\text { Hepatocurative } \\
\text { activity }\end{array}$ \\
\hline A. mexicana & $\mathrm{Ag}$ & Leaves & $20-50$ & Protein, & Antimicrobial \\
\hline Artemisia nilagirica & $\mathrm{Ag}$ & Leaves & $70-90$ & $\begin{array}{l}\text { Secondary } \\
\text { metabolites }\end{array}$ & Antimicrobial \\
\hline Boswellia serrata & $\mathrm{Ag}$ & Gum & $7-10$ & Protein, enzyme & Antibacterial \\
\hline Caria papaya & $\mathrm{Ag}$ & Fruit & 15 & $\begin{array}{l}\text { Hydroxyl flavones, } \\
\text { catechins }\end{array}$ & Antimicrobial \\
\hline Cassia fistula & $\mathrm{Ag}$ & Stem & $55-98$ & Hydroxyl group & Antihypoglycemic \\
\hline Cinnamon zeylanicum & $\mathrm{Ag}$ & Leaves & 45 & $\begin{array}{l}\text { Water soluble } \\
\text { organics }\end{array}$ & Antibacterial \\
\hline Citrullus colocynthis & $\mathrm{Ag}$ & Calli & $5-70$ & Polyphenols & $\begin{array}{l}\text { Antioxidant, } \\
\text { anticancer }\end{array}$ \\
\hline Citrus sinensis & $\mathrm{Ag}$ & Peel & 35 & $\begin{array}{l}\text { Water soluble } \\
\text { compounds }\end{array}$ & Antibacterial \\
\hline Dillenia indica & $\mathrm{Ag}$ & Fruit & $11-24$ & Biomolecules & Antibacterial \\
\hline Dioscorea bulbifera & $\mathrm{Ag}$ & Tuber & $8-20$ & $\begin{array}{l}\text { Diosgenin, ascorbic } \\
\text { acid }\end{array}$ & Antimicrobial \\
\hline Euphorbia prostrata & $\mathrm{Ag}$ & Leaves & 52 & $\begin{array}{l}\text { Protein, } \\
\text { polyphenols }\end{array}$ & Antiplasmodial \\
\hline $\begin{array}{l}\text { Gelsemium } \\
\text { sempervirens }\end{array}$ & $\mathrm{Ag}$ & whole & 112 & $\begin{array}{l}\text { Protein, amide, } \\
\text { amine group }\end{array}$ & Cytotoxicity \\
\hline Lippia citriodora & $\mathrm{Ag}$ & Leaves & $15-30$ & $\begin{array}{l}\text { Isoverbascoside } \\
\text { compound }\end{array}$ & Antimicrobial \\
\hline Mentha piperita & $\mathrm{Au}, \mathrm{Ag}$ & Leaves & $90-150$ & Menthol & Antibacterial \\
\hline Mirabilis jalapa & $\mathrm{Au}$ & Flowers & _ 100 & Polysaccharides & Antimicrobial \\
\hline H. canadensis & $\mathrm{Ag}$ & Whole & 113 & Phenolics, protein & Cytotoxicity \\
\hline Iresineherbstii & $\mathrm{Ag}$ & Leaves & $44-64$ & $\begin{array}{l}\text { Biomolecules } \\
\text { phenolic compound }\end{array}$ & Biological activities \\
\hline Melia azedarach & $\mathrm{Ag}$ & Leaves & 78 & $\begin{array}{l}\text { Tannic acid, } \\
\text { polyphenols }\end{array}$ & Cytotoxicity \\
\hline Tinospora cordifolia & $\mathrm{Ag}$ & Leaves & 34 & Phenolic compound & Antilarvicidal \\
\hline $\begin{array}{l}\text { Trigonella- } \\
\text { foenumgraecum }\end{array}$ & $\mathrm{Au}$ & Seed & $15-25$ & Flavonoids & Catalytic \\
\hline Withania somnifera & $\mathrm{Ag}$ & Leaves & $5-40$ & $\begin{array}{l}\text { Methyl 7- } \\
\text { oxooctadecanoate }\end{array}$ & Antimicrobial \\
\hline
\end{tabular}


Table.2 Summary of microbial derived metallic nanoparticles ((Kuppusamy et al., 2016)

\begin{tabular}{|c|c|c|c|}
\hline S. L & Bacterial strain & Shape & Functional groups \\
\hline 1 & Escherichia coli DH5a & Spherical & - \\
\hline 2 & Escherichia coli & Spherical & SH (thiol group) \\
\hline 3 & Rhodopseudomonas capsulata & Spherical & - \\
\hline 4 & Shewanella algae (ATCC 51181) & Spherical & Carbonyl group $(\mathrm{C}=\mathrm{O})$ \\
\hline 5 & bacillus & Spherical & Amino, sulfhydral and carboxyl groups \\
\hline 6 & Bacillus stearothermophilus & Triangle and other shapes & - \\
\hline 7 & Spirulina platensis & Spherical & $-\mathrm{NH}$ functional group \\
\hline 8 & Stenotrophomonas maltophilia & Spherical & - \\
\hline 9 & Geobacillus stearothermophilus & Spherical & $\begin{array}{l}\text { Amide I and II (due to CO stretch and }-\mathrm{N}-\mathrm{H} \text { stretch } \\
\text { vibrations in the amide linkages of proteins) }\end{array}$ \\
\hline 10 & $\begin{array}{l}\text { Magnetospirillum } \\
\text { gryphiswaldense MSR-1 }\end{array}$ & Spherical & - \\
\hline 11 & $\begin{array}{l}\text { Aureobasidium pullulans, } \\
\text { Fusarium oxysporumand Fusarium }\end{array}$ & Spherical & Amide II and aldehydes (A. pullulans) \\
\hline 12 & Alternaria alternata & Spherical and triangular & $\begin{array}{l}\mathrm{O}-\mathrm{H} \text { stretching, } \mathrm{C}-\mathrm{H} \text { stretching (proteins and other } \\
\text { organic residues), amide I (polypeptides) amide III } \\
\text { bands (the random coil of protein) }\end{array}$ \\
\hline 13 & Botrytis cinerea & Triangular & - \\
\hline 14 & Penicillium crustosum & Spherical & $\begin{array}{l}\text { Amide, carboxylic stretch (methylene groups of the } \\
\text { protein) } \mathrm{N}-\mathrm{H} \text { bend (primary amines, carbonyl } \\
\text { stretch in proteins) }\end{array}$ \\
\hline 15 & Penicillium chrysogenum & Spherical, triangle and rod & - \\
\hline 16 & Rhizopus oryzae & Spherical & Carboxyl and amine \\
\hline 17 & Neurospora crassa & Spherical & - \\
\hline 18 & Fusarium semitectum & Spherical & Amide I and amide II \\
\hline 19 & Trichoderma harzianum & Spherical & $\begin{array}{l}\mathrm{N}-\mathrm{H} \text { stretching, }-\mathrm{OH} \text { group from the carbohydrates } \\
\text { or protein, }-\mathrm{SH} \text { group indicating the presence of } \\
\text { cysteine in the biomass. }\end{array}$ \\
\hline 20 & Trichoderma viridehypocrealixii & Spherical & - \\
\hline
\end{tabular}

Fig.1 Schematic representation of microbial assisted synthesis of nanoparticles. A: Intracellular synthesis, B:

Extracellular synthesis

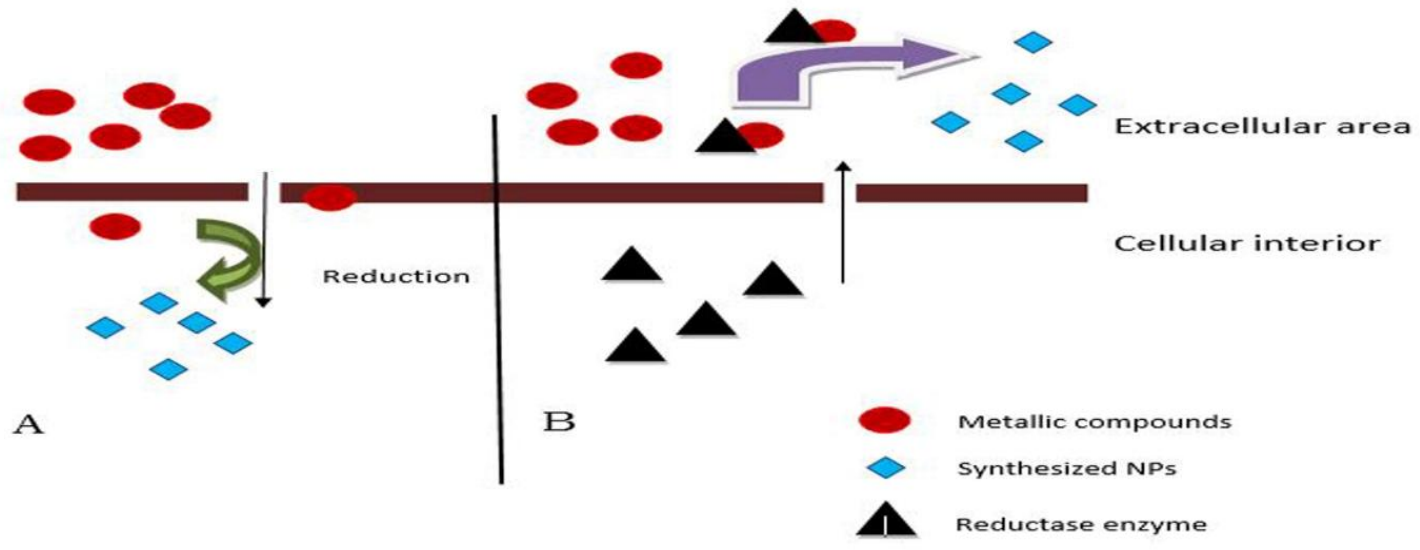


The AgNPs have effective drug in cancer medicine to cure various oncology and dreadful diseases. P. nigrum extracts have been longumine and piper longminine, it acts as a capping agent for the formation of silver nanoparticles and may enhance the cytotoxic effects of the tumour cells (Jacob et al., 2012). A green synthesis of silver nanoparticles using the leaves of Artemisia nilagirica plant extract has been described by (Vijayakumar et al., 2013). It shows a significant tool for antimicrobial agents in present and in a near future. Similarly, silver nanoparticles synthesized from the plant resources possibly control different pathogenic condition in human.

Noruzi et al., (2011) reported an eco-friendly method for the synthesis of gold nanoparticles by using rose petals. The extract medium contains abundant sugars and proteins. These functional compounds are the main sources for reduction of tetrachloroaurate salt into bulk GNPs. Likewise, Catharanthus roseus and Clitoria ternatea diverse groups of flowers are used for the metallic nanoparticle synthesis with desired sizes and shapes. The plant synthesized nanoparticles have been effectively controlling harmful pathogenic bacteria and similarly the medicinal usable Nyctanthes arbortristis flowers of gold nanoparticles extract are synthesized via green chemistry method (Das et al., 2011). The aqueous extract of Mirabilis jalapa flowers acts as a reducing agent and produced gold nanoparticles with ecofriendly method (Vankar and Bajpai, 2010). Some more examples of nanoparticles synthesized by plants and its applications have been tabulated in Table 2 .

\section{Biotechnological application of metallic nanoparticles}

The AgNPs were effectively disrupting the polymer subunits of cell membrane in pathogenic organisms. The reciprocal action of nanoparticles subsequently breaks the cell membrane and disturbs the protein synthesis mechanism in the bacterial system (Sondi and SalopekSondi, 2004). The increasing concentrations of silver nanoparticles have faster membrane permeability than the lower concentrations and consequently rupture the cell wall of bacteria (Kasthuri et al., 2009). The maximum conductivity was observed in Rhizophora apiculata reduced silver nanoparticles shown a low number of bacterial colony in the experimental plate compared with $\mathrm{AgNO}_{3}$ treated cells, which may be due to the smaller size of the particles and larger surface area which leads to the increase of membrane permeability and cell destruction (Antony et al., 2011). The interactions of bacteria and the metallic silver and gold nanoparticles have been binding with active site of cell membrane to inhibit the cell cycle functions (Kim et al., 2007). The biosynthesized silver nanoparticles were achieved in a single step procedure by using Citrus sinensis peel extract as a reducing and a capping agent. $C$. sinensis peel extract reduced silver nanoparticles effectively and the activity against Escherichia coli, Pseudomonas aeruginosa (gram-negative) and Staphylococcus aureus (gram-positive) has been identified (Kaviya et al., 2011).

Anti-inflammation is a cascade process that produces immune responsive compound such as interleukins and cytokinins which can be produced by keratinocytes including $\mathrm{T}$ lymphocytes, $\mathrm{B}$ lymphocytes and macrophages (Jaco et al., 2012). Various inflammatory mediators such as enzymes, antibodies are secreted from the endocrine system. Other potential anti-inflammatory agents such as cytokines, IL-1, IL-2 are secreted from the primary immune organs. These anti-inflammatory mediators induce the healing process (Satyavani et al., 2011). Also, the inflammatory mediators are involved in biochemical pathways and control the expansion of diseases. Biosynthesized gold nanoparticles achieved positive wound repair mechanisms and tissue regeneration in inflammatory function (Gurunathan et al., 2009). The studies proved that biosynthesized gold and platinum nanoparticles are alternative sources for treating inflammation in a natural way.

The overexpression of cellular growth will be arrested and regulated with systematic cell cycle mechanisms in cancerous cell by using bio-based nanoparticles as novel controlling agents(Akhtar et al., 2013). Also the plant mediated nanoparticles have great effect against various cancer cell lines such as Hep 2, HCT 116 and Hela cell lines. Recently, many studies reported that plant derived nanoparticles have potential to control tumour cell growth. The improved cytotoxic effect is due to the secondary metabolites and other non-metal composition in the synthesizing medium (Raghunandan et al., 2011) The plant derived silver nanoparticles regulate the cell cycle and enzymes in bloodstream (Alt et al., 2004) Moreover, the plant synthesized nanoparticles relatively control the free radicals formation from the cell. Free radicals commonly induce cell proliferation and damage the normal cell function. The moderate concentration of gold nanoparticles induces the apoptosis mechanism in malignant cells (Dipankar and Murugan, 2012). Similarly, Ag nanoparticles treated MCF-7 cancer cell line has retained the biomolecules concentration in the cells, and subsequently the cell metabolism was 
regulated (Das et al., 2013). The metallic nanoparticles have proved their novel applications in medical field to diagnose and treat various types of cancer and other retroviral diseases. The biobased nanoparticles are new and revolutionized to treat malignant deposit and without interfering the normal cells.

Biosynthesis of metal nanoparticles is extremely studied in the last two decades. The natural metabolites induce the production of metallic nanoparticles in ecofriendly manner. As a prospect, the ecofriendly synthesis of nanoparticlesin a large scale could enhance the biotechnological applications

\section{References}

Ahmad, S., Senapati, M., Khan, I., Kumar, R., Sastry, M., 2003. Extracellular biosynthesis of monodisperse gold nanoparticles by a novel extremophilic Actinomycete, Thermomonospora sp. ACS Symp. Ser. Am. Chem. Soc 19, 3550-3553.

Akhtar, M.S., Panwar, J., Yun, Y.-S., 2013. Biogenic synthesis of metallic nanoparticles by plant extracts. ACS Sustain. Chem. Eng 1, 591-602.

Alt, V., Bechert, T., Steinrücke, P., Wagener, M., Seidel, P., Dingeldein, E., Domann, E., Schnettler, R., 2004. An in vitro assessment of the antibacterial properties and cytotoxicity of nanoparticulate silver bone cement. Biomaterials 25, 4383-4391. doi: https://doi.org/10.1016/j.biomaterials.2003.10.078

Amarnath, K., Kumar, J., Reddy, T., Mahesh, V., Ayyappan, S.R., Nellore, J., 2012. Synthesis and characterization of chitosan and grape polyphenols stabilized palladium nanoparticles and their antibacterial activity. Colloids Surfaces B Biointerfaces 92, 254-261. doi: 10.1016/j.colsurfb.2011.11.049

Antony, J.J., Sivalingam, P., Siva, D., Kamalakkannan, S., Anbarasu, K., Sukirtha, R., 2011. Comparative evaluation of antibacterial activity of silver nanoparticles synthesized using Rhizophora apiculata and glucose. Colloid Surf. B 98, 65-72.

Cai, F., Li, J., Sun, J., Ji, Y., 2011. Biosynthesis of gold nanoparticles by biosorption using Magnetospirillum gryphiswaldense MSR-1. Chem. Eng. J. 175, 70-75. doi: https:// doi.org/10.1016/j.cej.2011.09.041

Castro, L., Blazquez, M.L., Munoz, J.A., Ballester, A., 2012. Biological synthesis of metallic nanoparticles using algae. IET Nanobiotechnol. doi:10.1049/ietnbt. 2012.0041

Das, R.K., Gogoi, N., Bora, U., 2011. Green synthesis of gold nanoparticles using Nyctanthes arbortristis flower extract. Bioprocess Biosys. Eng., 34, 615619.

Das, S., Das, J., Samadder, A., Bhattacharyya, S.S., Das, D., Khuda-Bukhsh, A.R., 2013. Biosynthesized silver nanoparticles by ethanolic extracts of Phytolacca decandra, Gelsemium sempervirens, Hydrastis canadensis and Thuja occidentalis induce differential cytotoxicity through G2/M arrest in A375 cells. Colloids Surfaces B Biointerfaces 101, 325-336.

doi:https://doi.org/10.1016/j.colsurfb.2012.07.008

Davis, T.A., Volesky, B., Mucci, A., 2003. A review of the biochemistry of heavy metal biosorption by brown algae. Water Res. 37, 4311-4330. doi: https://doi.org/10.1016/S0043-1354(03)00293-8

Dipankar, C., Murugan, S., 2012. The green synthesis, characterization and evaluation of the biological activities of silver nanoparticles synthesized from Iresine herbstii leaf aqueous extracts. Colloids Surfaces B Biointerfaces 98, 112-119. doi: https://doi.org/10.1016/j.colsurfb.2012.04.006

Du, L., Jiang, H., Liu, X., Wang, E., 2007. Biosynthesis of gold nanoparticles assisted by Escherichia coli DH5 $\alpha$ and its application on direct electrochemistry of hemoglobin. Electrochem. commun. 9, 11651170. doi:https://doi.org/10.1016/j.elecom.2007. 01.007

Fayaz, M., Mashihur, G.M., Rahman, P.T.K., 2011. Biosynthesis of silver and gold nanoparticles using thermophilic bacterium Geobacillus stearothermophilus. Process Biochem. 46, 19581962.

Gomathy, M., Sabarinathan, K.G., 2010. Microbial mechanisms of heavy metal tolerance - a review. Agric. Rev., 31, 133-138.

Gopinath, V., MubarakAli, D., Priyadarshini, S., Priyadharsshini, N.M., Thajuddin, N., Velusamy, P., 2012. Biosynthesis of silver nanoparticles from Tribulus terrestris and its antimicrobial activity: A novel biological approach. Colloids Surfaces B Biointerfaces 96, 69-74. doi:https://doi.org/10.1016/ j.colsurfb.2012.03.023

Gurunathan, S., Lee, K.-J., Kalishwaralal, K., Sheikpranbabu, S., Vaidyanathan, R., Eom, S.H., 2009. Antiangiogenic properties of silver nanoparticles. Biomaterials 30, 6341-6350. doi: https://doi.org/10.1016/j.biomaterials.2009.08.008

Jaco, S.J.P., Finub, J.S., Narayanan, A., 2012. Synthesis of silver nanoparticles using Piper longum leaf extracts and its cytotoxic activity against Hep-2 cell line. Colloid Surf. B 91, 212-2-14. 
Jacob, S.J.P., Finub, J.S., Narayanan, A., 2012. Synthesis of silver nanoparticles using Piper longum leaf extracts and its cytotoxic activity against Hep-2 cell line. Colloid Surf. B, 91, 212-214.

Kasthuri, J., Kathiravan, K., Rajendiran, N., 2009. Phyllanthin assisted biosynthesis of silver and gold nanoparticles: a novel biological approach. J. Nanopart. Res 11, 1075-1085.

Kaviya, S., Santhanalakshmi, J., Viswanathan, B., Muthumary, J., Srinivasan, K., 2011. Biosynthesis of silver nanoparticles using Citrus sinensis peel extract and its antibacterial activity. Spectrochim. Acta Part A Mol. Biomol. Spectrosc. 79, 594-598. doi:https://doi.org/10.1016/j.saa.2011.03.040

Kim, J.S., Kuk, E., Yu, K.N., Kim, J.-H., Park, S.J., Lee, H.J., Kim, S.H., Park, Y.K., Park, Y.H., Hwang, C.Y., Kim, Y.-K., Lee, Y.-S., Jeong, D.H., Cho, M.H., 2007. Antimicrobial effects of silver nanoparticles. Nanomedicine Nanotechnology, Biol. Med. 3, 95-101. doi:https://doi.org/10.1016/j.nano. 2006.12.001

Krishnaraj, C., Muthukumaran, P., Ramachandran, R., Balakumaran, M.D., Kalaichelvan, P.T., 2014. Acalypha indica Linn: Biogenic synthesis of silver and gold nanoparticles and their cytotoxic effects against MDA-MB-231, human breast cancer cells. Biotechnol. Reports 4, 42-49. doi:10.1016/j.btre.2014.08.002

Kumar, D.A., Palanichamy, V., Roopan, S.M., 2014. Green synthesis of silver nanoparticles using Alternanthera dentata leaf extract at room temperature and their antimicrobial activity. Spectrochim. Acta Part A Mol. Biomol. Spectrosc. 127, 168-171. doi:https://doi.org/10.1016/j.saa. 2014.02.058

Kuppusamy, P., Yusoff, M.M., Maniam, G.P., 2016. Biosynthesis of metallic nanoparticles using plant derivatives and their new avenues in pharmacological applications - An updated report. Saudi Pharm. J. 24, 473-484. doi:10.1016/j.jsps.2014.11.013

Lirdprapamongkol, K., Warisnoicharoen, W., Soisuwan, S., Svasti, J., 2014. Eco-Friendly synthesis of fucoidan-stabilized gold nanoparticles. Am. J. Appl. Sci 7, 1038-1104.

Luo, P., Liu, Y., Xia, Y., Xu, H., Xie, G., 2014. Aptamer biosensor for sensitive detection of toxin A of Clostridium difficile using gold nanoparticles synthesized by Bacillus stearothermophilus. Biosens. Bioelectron. 54, 217-221. doi: https://doi.org/10.1016/j.bios.2013.11.013

Mariselvam, R., Ranjitsingh, A.J.A., Usha Raja Nanthini,
A., Kalirajan, K., Padmalatha, C., Mosae Selvakumar, P., 2014. Green synthesis of silver nanoparticles from the extract of the inflorescence of Cocos nucifera (Family: Arecaceae) for enhanced antibacterial activity. Spectrochim. Acta Part A Mol. Biomol. Spectrosc. 129, 537-541. doi:https://doi.org/10.1016/j.saa.2014.03.066

Menon, S., S., R., S., V.K., 2017. A review on biogenic synthesis of gold nanoparticles, characterization, and its applications. Resour. Technol. 3, 516-527. doi: https://doi.org/10.1016/j.reffit.2017.08.002

Mittal, A.K., Chisti, Y., Banerjee, U.C., 2013. Synthesis of metallic nanoparticles using plant extracts. Biotechnol. Adv. 31, 346-356. doi: https://doi.org/10.1016/j.biotechadv.2013.01.003

Noruzi, M., Zare, D., Khoshnevisan, K., Davoodi, D., 2011. Rapid green synthesis of gold nanoparticles using Rosa hybrida petal extract at room temperature. Spectrochim. Acta Part A Mol. Biomol. Spectrosc. 79, 1461-1465. doi: https://doi.org/10.1016/j.saa.2011.05.001

Raghunandan, D., Ravishankar, B., Sharanbasava, G., Mahesh, D.B., Harsoor, V., Yalagatti, M.S., Bhagawanraju, M., Venkatarama, A., 2011. Anticancer studies of noble metal nanoparticles synthesized using different plant extracts. Cancer Nanotechnol 2, 57-65.

Satyavani, K., Gurudeeban, S., Ramanathan, T., Balasubramanian, T., 2011. Biomedical potential of silver nanoparticles synthesized from calli cells of Citrullus colocynthis (L.) Schrad. J. Nanobiotechnol. 9, 43-51.

Shameli, K., Ahmad, M., Mulla, A., Ibrahim, E.A.., Shabanzadeh, N.., Rustaiyan, P., Abdollahi, Y., 2012. Green biosynthesis of silver nanoparticles using Callicarpa maingayi stem bark extraction. Molecules 17, 8506-8517.

Sondi, I., Salopek-Sondi, B., 2004. Silver nanoparticles as antimicrobial agent: a case study on E. coli as a model for Gram-negative bacteria. J. Colloid Interface Sci. 275, 177-182. doi: https://doi.org/10.1016/j.jcis.2004.02.012

Suganya, K.S.U., Govindaraju, K., Kumar, G., Manickan, E., 2015. Blue green alga mediated synthesis of gold nanoparticles and its antibacterial efficacy against Gram positive organisms. Mater. Sci. Eng. C Mater. Biol. Appl. C 351-356.

Suresh, A.K., Pelletier, D.A., Wang, W., Broich, M.L., Moon, J.-W., Gu, B., Allison, D.P., Joy, D.C., Phelps, T.J., Doktycz, M.J., 2011. Biofabrication of discrete spherical gold nanoparticles using the metal-reducing bacterium Shewanella oneidensis. 
Acta Biomater. 7, 2148-2152. doi:https://doi. org/10.1016/j.actbio.2011.01.023

Suriyakalaa, U., Antony, J.J., Suganya, S., Siva, D., Sukirtha, R., Kamalakkannan, S., Pichiah, P.B.T., Achiraman, S., 2013. Hepatocurative activity of biosynthesized silver nanoparticles fabricated using Andrographis paniculata. Colloids Surfaces B Biointerfaces 102, 189-194. doi:https://doi.org/ 10.1016/j.colsurfb.2012.06.039

Thakkar, K.N., Mhatre, S.S., Parikh, R.Y., 2010. Biological synthesis of metallic nanoparticles. Nanomedicine Nanotechnology, Biol. Med. 6, 257262. doi:https://doi.org/10.1016/j.nano.2009.07.002

Vanaja, M., Rajeshkumar, S., Paulkumar, K., Gnanajobitha, G., Malarkodi, C., Annadurai, G., 2013. Phytosynthesis and characterization of silver nanoparticles using stem extract of Coleus aromaticus. Int. J. Mater. Biomat. Appl. 3.

Vankar, P.S., Bajpai, D., 2010. Preparation of gold nanoparticles from Mirabilis jalapa flowers. Indian J. Biochem. Biophys 47.

Venkatesan, J., Manivasagan, P., Kim, S.K., Kirthi, A.V., Marimuthu, S., Rahuman, A.A., 2014. Marine algae-mediated synthesis of gold nanoparticles using a novel Ecklonia cava. Bioprocess Biosyst. Eng. doi: 10.1007/s00449-014-1131-7

Vijayakumar, M., Priya, K., Nancy, F.T., Noorlidah, A., Ahmed, A.B.A., 2013. Biosynthesis, characterisation and anti-bacterial effect of plantmediated silver nanoparticles using Artemisia nilagirica. Ind. Crops Prod. 41, 235-240. doi: https://doi.org/10.1016/j.indcrop.2012.04.017

Zhang, X., He, X., Wang, K., Yang, X., 2011. Different active biomolecules involved in biosynthesis of gold nanoparticles by three fungus species, plant resources conservation and utilization research. J. Biomed. Nanotechnol. 7, 53-64.

How to cite this article:

Durairasu, M. and Indira, V. 2018. Nanotechnology: Current Scenario and Future Aspects. Int.J.Curr.Res.Aca.Rev. 6(4), 20-28. doi: https://doi.org/10.20546/ijcrar.2018.604.004 